\title{
O Judiciário e o Estado Brasileiro: Poder, Democracia e Estado de Direito
}

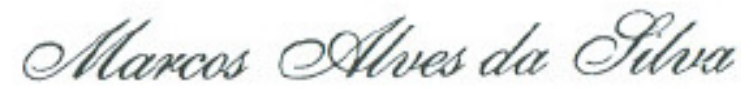

Mestrando em Direito das Relações Sociais pela Universidade

Federal do Paraná, advogado em Curitiba.

“Os príncipes que quiseram transformar-se em tiranos começaram sempre reunindo na sua pessoa todas as funções públicas."

\section{Introdução}

Estado moderno e seus fundamentos encontram-se em profunda crise neste apagar das luzes do século XX. Dogmas consagrados estão, hoje, sob suspeita. No âmago da crise, o Judiciário.

Neste breve estudo, busca-se articular questões preliminares de fundo para a compreensão do papel do Poder Judiciário no estado contemporâneo. Na primeira parıe, deủica-se especial âtençc̃o à cunsis uçãu teórica da divisão dos poderes, sendo inarredável a referência a MONTESQUIEU. A segunda é direcionada à analise do Judiciário enquanto poder e à evolução histórica de suas atribuições, merecendo destaque o modelo da judicial review, norte-americano, e o modelo europeu dos tribunais constitucionais, vez que em ambos se inspira o sistema constitucional brasileiro. A última parte tem em vista um exercício crítico, com o apontamento de algumas perspectivas.

A título de delimitação da abordagem é relevante assinalar que se pretende 
ter como parâmetro o campo da Teoria do Estado. Contudo, em razão do objeto de pesquisa, algumas vezes tangenciou-se a esfera do direito constitucional. Isto, em razão do papel eminentemente político do controle da constitucionalidade. Fica, portanto, esclarecido que a menção de conceitos típicos do direito constitucional tem caráter meramente assessório.

Por fim, faz-se mister anotar que 0 presente estudo tem objetivo propedêutico, no sentido de apontar as questões de fundo, que envolvem o Judiciário, sem contudo abordar "temas de ponta", como a reforma do Judiciário, em andamento no Congresso Nacional, ou a tendência de retração da tutela jurisdicional sobre os direitos sociais, mormente os trabalhistas. Permanecem, assim, esses temas como indicativos para ulterior pesquisa.

\section{O Judiciário na gênese da construção teórica do Estado moderno}

Kemissao à obra de MONTESQUIEU é tarefa inafastável para o exercício de reflexão a que este estıdo se propõe. ${ }^{1}$ Constitui fundamento do Estado moderno a tripartição dos poderes, explicitada no Livro XI do Espírito das Leis. Bem observou PAULO BONAVIDES que "os primeiros juristas da Revolução Francesa, impressionados com o alcance [do conceito de liberdade de MONTESQUIEU, vinculado à tripartição dos poderes], o inscreveram no art. 16 da Declaração dos Direitos do Homem e do Cidadão". ${ }^{2}$ De tal sorte que a idéia dos três poderes constitutivos do Estado restou impregnada, daí em diante, na concepção do Estado moderno constitucional. E parece que este foi um desiderato do próprio autor. Ao concluir o Livro XI, depois de uma longa exemplificação histórica de sua teoria, arremata: "Mas é preciso que nem sempre se esgote de tal forma um assunto, a ponto de nada deixar para que o leitor também se esforce. Não se trata aqui de fazer ler, mas sim de fazer pensar". ${ }^{3}$ Indiscutivelmente, foi um vaticínio.

Uma reflexão, portanto, sobre o Poder Judiciário no contexto do Estado Brasileiro exige a retomada preliminar de alguns elementos da teoria de MONTESQLIEU, ${ }^{4}$ como exercício arqueológico. ${ }^{5}$

MONTESQUIEU tipifica as formas de governo, através de um duplo critério,

1. Com acerto afirmou Fernando Ruivo que "a verdadeira questâo do 'poder judicial" só surge reaimente no século XVIII, inserida na ofensiva politico-ideológica da burguesia revolucionária e tomando grande parte do seu peso na teoria da separação dos poderes". RUIVO, Fernando. Aparelho judicial, estado e legitimação. In FARIA, José Eduardo (Org.). Direito e justiça - a funçáo social do judiciário. 2. ed., Săc Paulo: Ática, 1994, p. 74.

2. Dispōe 0 art. 16 da Declaração Universal dos Direitos do Homem e do Cidadão: "Toda sociedade, onde a garantia dos direitos não seja assegurada nem a separação de poderes determinada, räo possui Constituição". BONAVIDES, Paulo. Teoria do estado. 2. ed., Rio de laneiro: Forense, 1980, p. 143.

3. MONTESQUIEU. Do espíito das leis. São Paulo: Brasil Editora, 1960 (?), p. 213.

4. Vale aqui ressaltar anotação de Bcbbio que L'Esprit des Lois "não é uma obra de teoria política, embora contenha uma teoria politica". BOBBIO, Norberto. A teoria das formas de formas de governo. 3. ed., Brasilia: Editora Universitária de Brasilia, 1980, p. 117.

5. A palavra arqueológico, aqui, é usada no sentido etimológico do termo (: princípio, fonte, origem). 
em republicano, monárquico e despótico. Tal classificação mereceria atenção especial, que foge ao escopo do presentè trabalho. ${ }^{6}$ Porém, ao lado dessa divisão horizontal do poder, para usar a imagem de Bobbio, ressalta-se, na obra de MONTESQUIEU, a divisão vertical, que veio a constituir sua "célebre teoria da separação dos poderes". ${ }^{7}$ Desta passamos a revisitar alguns pontos.

A liberdade é questão fuicral a partir da qual MONTESQUIEU constrói sua teoria. Sintetiza: "A liberdade é o direito de fazer aquilo que as leis permitem; e, se um cidadão pudesse fazer aquilo que as leis proíbem, ele já não teria mais liberdade, porque os outros teriam também esse mesmo poder". 8

Daí, passa à assertiva de que não existem estados livres por natureza própria. Para o autor do Espírito das Leis só há liberdade onde não se abusa do poder, porém todo homem que detém o poder tende, inexoravelmente, a abusar do mesmo, e nesse propósito irá até que encontre um limite. Como corclário deste arrazonde ficou célebre sua frase: "Para que não se possa abusar do poder, é preciso que, pela disposição das coisas, o poder refreie o próprio poder". (grifamos)
Seu pensamento é de uma clareza solar e de uma simplicidade não vulgar. Pre missa maior: "A liberdade política, num cidadão, é a tranqüilidade de espírito que provém da opiniāo que cada um possui de sua segurança; e, para que se possua essa liberdade, é preciso que o governo seja tal que um cidadão não possa temer a um outro". ${ }^{10}$ Premissa menor: "Quando, numa só pessoa ou num mesmo corpo de magistratura, c poder legislativo se acha reunide ao poder executivo, não poderá existir a liberdade, porque se poderá temer que o mesmo monarca ou o mesmo senado criem leis tirânicas, para executá-las tiranicamente.(...) $\mathrm{E}$, se estiver unido ao poder executivo, o juiz poderá ter a força de um opressor". ${ }^{11}$ Conclusão (implícita): Há necessidade da partição dos poderes, para assegurar a liberdade dos cidadãos.

Porém, da leitura do Livro XI do Espírito das Leis, se deflui que MONTESQUIEU faz menoscabo do Poder Judiciário. Aliás, afirma explicitamente: "Dos três poderes dos quais falamos, o judiciário é de algum modo nulo". ${ }^{12}$ Para ele, os poderes políticos, por excelência, seriam o legislativo e o executivo. O primeiro porque portador da representatividade popu-

\section{Bobbio qualificou de anómala a classiicação de Montesquieu em razão dele misturar dois critérios diferentes para o estabeleci- mento de sua classilicação, pois, através do critério dos sujeitos do poder soberano, ele separa a monarquia e a república, e, pelo modo de governar, ele distingue entre monarquia e despotismo (ct. BOBBIO, Norbertb. Op. cit. p. 120). Montesquieu enumera os princípios animadores de cada uma dessas formas de governo: a virtude civica para a república; a honra para a monarquia; 0 medo para o despotismo (Cf. MONTESQUIEU. Op. cit., pp. 17/30).}

7. Idem. p. 126.

8. MONTESQUIEU. Do espirito das leis. São Paulo: Brasil Editora, 1960 (?), p. 178.

9. Idem. p. 179

10. Idem. p. 180. Observe-se que nesse enunciado parece haver certa similitude com a preocupaçăo hobbesiana.

11. Ibidem.

12. Idem. p. 184 
lar e o segundo por sua ação instantânea e efetiva. ${ }^{13}$

$\mathrm{Na}$ idealização tripartida de poder de MONTESQUIEU, o poder de julgar não deveria ser concedido a um corpo permanente de magistrados. Mas seria exercido por pessoas retiradas das classes populares, que exerceriam as funções de magistrado por determinado período. "Tornar-se-á, por assim dizer, invisível e nulo. E ninguém mais terá, continuamente, juízes diante dos olhos; temer-se-á a magistratura, e não mais os magistrados". ${ }^{14}$

A utilização do termo nulo parece sugerir, também, uma concepção de juiz destituído de vontade própria, submetido de forma insofismável à lei. Assim, o Judiciário não seria, de fato, um poder político, mas, um órgão da administração estatal responsável pela execução da lei, aplicando-a aos casos concretos, tanto para punir, como para resolver os litígios entre os particulares. Esta concepção do Judiciário será exposta por MONTESQUIEU de forma iñequíivoca. "Se os Tribunais nãc devem ser fixos, os julgamentos deverão sê-lo a um ponto tal que não representem nunca senão o texto fixo da lei. Se representassem uma opinião particular do juiz, viver-se-ia na sociedade sem saber com se- gurança quais os compromissos que nela se contratam". ${ }^{15}$

Dois aspectos merecem, aqui, ser notados. Primeiro, esta concepção neutral do juiz, formulada ou reforçada por MONTESQUIEU, não subsiste, muito embora tenha ganhado, desde então até bem pouco, ardorosos adeptos, tornandose, assim, emblemática de um mascaramento ideológico, hoje, desvelado, especialmente, pela sociologia do direito. Segundo, a teoria de MONTESQUIEU posta, à prova pelas revoluções burguesas, principalmente a Americana, mostrou-se frágil, quando fez fraco ou nulo o Judiciário. A experiência federalista norte-americana teve a grande virtude de indicar o lugar fundamental de um Judiciário que não fosse nulo. É do que se passará a tratar.

\section{A essência do poder judiciário}

A pergunta que tenciona a mola para impulsionar a incureão que aqui, modestamente, se pretende, pode ser formulada de diferentes modos: $\mathrm{O}$ que faz do Judiciário um poder, livrando-o de ser um mero órgão da administração pública ou da nulidade, referida por MONTESQUIEU? Que papel

13. A teoria da representatividade do legislativo é central neste ponto da reflexão de Montesquieu, e ele náo nega sua adesão à bipartiçăo deste poder em duas câmaras: uma da nobreza (princípio hereditário) e outra da popular (princípio eletivo). E para 0 exercício do poder executivo o ideal seria um monarca. Montesquieu nāo dissimula sua admiraçáo pelo modelo britânico. Ao contrário, toma-o protótipo para sua incursão pelo tema do poder. Porém, como bem frisou Paulo Bcnavides, 'dizer que Montesquieu foi apenas o vulgarizador da Constituiçăo inglesa, o discipulo fervoroso de Locke, seria fazer grave injustiça ao pensador (...) que lançou ao liberalismo as bases sobre as quais assentou no Ocidente a moderna experiência governativa do século XIX'. Op. cit., p. 123

14. Op. cit., p. 182.

15. Idem. p. 182. 
cumpre o Judiciário na organização estruturante do Estado moderno? Como este papel foi-se, historicamente, delineando?

No modelo liberal, as decisões judiciais - que pacificam os litígios entre particulares e que penalizam os delituosos, em última análise, e considerada a visão clássica do juiz estritamente vinculado à lei e ileso de influências subjetivas de sua condição humana - não caracterizam um poder, porque do juiz se subtrai, ao menos teoricamente, qualquer discricionariedade, portanto, vontade e poder inexistiriam. Contudo, como se procurará demonstrar, o Poder Judiciário encontrará seu locus, enquanto poder, na estrutura do estado, em face da constituição. E este lugar provocará uma profunda mudança do perfil que lhe fora estabelecido a princípio.

O Estado moderno é, essencialmente, o estado constitucional; e o estado de uma constituição consubstanciada em um documento fundamental. Bem explicita CANOTILHO: "a ordenação da comunidade política, através de um documento escrito, de uma lei formal-constitucional, torna claro que para o constitucionalismo a constituição já não é o modo de ser de ordenação da comunidade, mas o ato constitutivo dessa ordenação no plano sensível". ${ }^{16}$ Será como guardião deste pacto furidante do estado, da lex fundamentalis, que o poder do Judiciário ganhará contornos mais claros.
As constituiçōes surgem para se impor freio ao poder dos monarcas. Pelo fato da Inglaterra não possuir uma constituição formalizada em um único documento, é comum referir-se à constituição inglesa como costumeira, tal não é de todo verdadeiro. As constituições propriamente costumeiras são, por exemplo, as do Ancien Régime, na França, antes da Revolução de 1789 , caracterizadas por uma complexa massa de usos e costumes e decisões judiciais. ${ }^{17} \mathrm{~A}$ pré-história do constitucionalismo, como ressalta CANOTILHO, tem início na própria Inglaterra, quando, em 1215, os barōes impuseram a João-Sem-Terra a Magna Charta Libertatum e, em 1628, com a Petition of Right, o Parlamento tomava posição, ao menos declaratória, com respeito aos princípios fundamentais das liberdades civis. ${ }^{18}$

Será porém, com o surgimento das constituições chamadas rígidas pela dogmática constitucional, que aflorará o Poder Judiciário, enquanto tal.

\subsection{A judicial review (a importância do modelo norte-americano)}

Neste sentido, a referência à experiência norte-americana torna-se imprescindível, vez que a primeira Constituição Republicana Brasileira inspirou-se, fundamentalmente, naquele modelo estatal.

A mais expressiva contribuição do modelo estadunidense diz respeito ao me-

\footnotetext{
16. CANOTILHO, José Joaquim Gomes. Direito Constitucional. 6. ed., Coimbra: Almedina, 1993, p. 64.

17. BONAVIDES, Paulo. Curso de Direito Constitucional. 4. ed., São Paulo: Malheiros, 1993, p. 67.

18. Op. cit., p. 61.
} 
canismo da judicial review, que vai garantir à ordem constitucional certa estabilidade $\mathrm{e}$ supremacia. E, como assinala o Ministro JOSÉ NÉRI DA SILVEIRA, "a chamada judicial review revela manifesto 'poder político', porquanto, se este existe no órgão que faz a lei, importa entender, inafastavelmente, estar presente, por igual, no órgão que dispõe de império para declarar-lhe a invalidade. (...) No controle sobre os atos do Legislativo e do Governo evidencia-se o caráter político de que está investido o Judiciário no desempenho da competência para proclamar a inconstitucionalidade ou invaiidade desses atos". ${ }^{19}$ De tal forma, será em decorrência do princípio da supremacia da constituição, que o Judiciário alcançará proeminência enquanto poder político.

Para uma referência ao modelo estadunidense, necessária se torna menção ao célebre aresto de JOHN MARSHALL, no caso Marbury versus Madison. Na Constituição norte-americana não há dispositivo expresso sobre o controle de constitucionalidade das leis. Foi, sim, a irretocável lógica da sentença desse juiz da Suprema Corte, que abriu caminho para a formulação de sistemas de controle da constitucionalidade das leis e atos normativos governamentais. A linha estrutural de seu raciocínio é assim descrita por PAULO BONAVIDES:
"Os poderes do legislativo são definidos e limitados, sendo essa limitação a causa das constituições escritas. Se não fossem eles definidos e limitados, por que reduzi-los à forma escrita, se a cada passo poderiam esses poderes ser alterados por aqueles cuja competência se pretende restringir? (...) Ou a constituição controla todo ato legislativo que a contrarie, ou o legislativo, por um ato ordinário, poderá modificar a constituição. (...) Ou a constituição é lei superior e suprema ou modificar-se-á ao arbítrio da legislatura. (...) [Logo], se um ato legislativo, oposto à Constituição, é nulo, como pode ele - interroga - sem embargo de sua invalidade, vincular tribunais e obrigá-los a teconhecer-lhe efeito? (...) À Corte compete determinar qual dessas regras antagônicas se aplica à espécie litigiosa, pois nisso consiste a essência do poder judiciário." ${ }^{20}$ (Grifamos)

A partir dessa decisão paradigmática de MARSHALL, no caso Marbury versus Madison, a Suprema Corte norte-americana, gradativamente, angariou proeminência política, tanto que se passou a falar da existência de um verdadeiro "governo de juízes". ${ }^{21}$

Assim, primeiro surge e aos poucos se sistematiza a doutrina do controle da constitucionalidade das leis por via de exceçāo - controle concreto. $\mathrm{O}$ passo seguinte será o controle por via de ação - controle abstrato. ${ }^{22}$

19. SILVEIRA, José Néri da. Aspectos institucionais e estruturais do poder jurídico urasileiro. In TEIXEIRA, Sálvio de Figueiredo. $O$ judiciário e a constituiçāo. Sāo Paulo: Saraiva, 1994, p. 3.

20. Op. cit., pp. 237-238.

21. Laski, citado por Bonavides afirma que "a inferência correta é a de que, em útima análise, a Suprema Corte, quando exerce o poder da judicial review, funciona de fato como um terceira Cåmara nos Estados Unidos". (LASKI, Herold J. The American democracy - a commentary and interpretation. London, 1953.) (Cf. Op. cit., p. 244).

22. Ao fim a que se propõe o presente trabalho não interessa o estudo propriamente do controle da constitucionalidade das leis, campo do direito constitucional. A mençāo que ora se faz tem por objetivo evidenciar apenas a relevància a que vai sendo guindado o Juciciário, na medida em que se expandem suas atrbuições de contrcle da constitucionalidade das leis. 
A via de exceção, ou via incidental, diz respcito à possibilidade de não aplicação de uma lei ao caso concreto, em razão de entender o juiz que tal lei afronta norma constitucional. Via de execução, porque "a inconstitucionalidade não se deduz como alvo da ação, mas apenas como subsídio da justificação do direito, cuja reivindicação se discute". ${ }^{23}$ Assim, aos cidadãos é garantido acesso a qualquer juiz, para que este se pronuncie sobre a aplicabilidade ou não de determinada lei a um caso concreto, tendo em vista sua constitucionalidade ou inconstitucionalidade. Em última análise, sobre o tema decide a Corte Suprema.

Se no modelo norte-americano temos a primeira intuição de um sistema de controle da constitucionalidade, de outro lado alguns constitucionalistas entendem que este sistema "não se caracteriza verdadeiramente como uma forma de jurisdição constitucional... pelo fato de que a jurisdição ordinária não aprecia a constituição em função de seus valores políticos, não configurando uma guardiã dos valores constitucionais, porque tem como objetivo principal a decisão do caso concreto". ${ }^{24}$

\subsection{O modelo europeu - os tribunais constitucionais}

Diferentemente do controle concreto, através de alegação preliminar prejudicial de inconstitucionalidade, a via de ação ou controle abstrato implica na impugnação da constitucionalidade de uma lei ou ato normativo, independentemente de qualquer litígio ou fato concreto. ${ }^{25}$ Geralmente, a legitimidade ativa para a propositura de uma ação direta de inconstitucionalidade é restrita a um número pequeno de entidades ${ }^{26}$ Este mecanismo é conhecido como sistema europeu de controle da constitucionalidade, que se institucionalizou a partir de 1920 , com a criação de tribunais constitucionais.

O sistema europeu surge em face de ataques políticos e ideológicos às constituições. Por isso, como observa JOSÉ AFON. SO DA SILVA, "a defesa não poderia ser senão de natureza política e ideológica”. ${ }^{27}$ A primeira Constituição que positivou tal sistema foi a da Áustria, tendo como grande inspirador HANS KELSEN. ${ }^{28}$

Tais tribunais constitucionais passaram a exercer poder políticn inegável, o que. conseqüentemente, contribuiu para elevar o Judiciário a um patamar de equiparação com os demais poderes. Segundo CANOTILHO,

23. Tal precisa definição é de Rui Barbosa, em Os atos inconstitucionais do Congresso e do Executivo. Apud. CANOTILHO, José Joaquim Gomes. Op. cit., p. 965.

24. SILVA, José Afonso da. Curso de direito constitucional. 8. ed., São Paulo: Malheiros, 1992, p. 484.

25. Cf. CANOTILHO, José Joaquim Gomes. Op. cit., p. 966.

26. As exceçð̌es são rarissimas. Paulo Bonavides menciona o caso da Suiça, onde as leis federais năo podem ser inquinadas de inconstitucionalidade, mas, por outro lado, as constituçōes e leis cantonais podem ser argüidas diretamente por qualquer cidadắo. Op. cit., p. 240.

27. Op. cit., p. 484.

28. Cf. Bonavides, Paulo. Op. cit., p. 240. 
"as decisões do Tribunal Constitucional acabam efetivamente por ter força política, não só porque a ele cabe resolver, em última instância, problemas constitucionais de especial sensibilidade política, mas também porque a sua jurisprudência produz, de fato ou de direito, uma influência determinante junto dos outros tribunais e exerce um papel condicionante do comportamento dos órgāos de direção política. ${ }^{.29}$ (destáque no texto original)

O constitucionalista lusitano pôe em relevo que, com a tarefa de guardião constitucional destes tribunais, conexionam-se questões políticas de primeira ordem, e enumera: "(1) defesa das minorias perante a onipotência da maioria parlamento-governo; (2) primazia hierárquico-normativa da Constituição e do legislador constituinte perante a onipotência da maioria parlamento-governo; (3) primazia do dogma tradicional da presunção de constitucionalidade dos atos legislativos; (4) legitimidade do desenvolvimento do próprio direito constitucional através da interpretação dada às normas da Constituição pelos juízes constitucionais". ${ }^{30}$ Os três primeiros pontos são de especial importância para a linha de reflexão que no presente estudo se busca equacionar, por isso, certamente, de uma forma ou de outra, serão a seu tempo retomados.

Assim, no modelo da ação política, muito mais que no modelo da via de exceção judicial, avulta-se o Judiciário enquanto poder. Alguns têm entendido que tal sistema afrontaria os demais órgâos da soberania. Entre nós, por exemplo, RUI BAR. BOSA, em razão da influência do constitucionalismo norte-americano, rechaçava por completo a via da ação. Dizia ele:

"Se fosse lícito levantar a ques. tão de constitucionalidade principal, em vez de incidentalmente, tratar o exame do ato ir.constitucional como objeto ime. diato da causa, e intentá-la solenemente como meio revogatório da lei ou decre. to, que se censura, a questão, ainda que de sua índole o não fosse, viria a se tornar política, pela sua forma, pela sua direção, pelo seu alcance. Política porque abriria combate entre os poderes da União, entregando a uma autoridade so. berana a cassação sobre os atos dos outros." 31

De fato, para o modelo teórico libe. ral típico, adotado pela primeira Constituição Republicana, o Judiciário deveria se ater à decisão dos casos concretos, mediante provocação dos particulares, restringindo. se à aplicação da lei. $\mathrm{O}$ controle abstrato da constitucionalidade dos atos do Legislativo e do Executivo seria incom. patível com o papel delineado para o Judi. ciário, no desenho liberal de modelo de estado.

\subsection{0 modelo brasileiro - sistema misto}

A princípio, como já dito, anteriormente, no Brasil, adotou-se o sistema

29. Op. cit, p. 765.

30. Idem, ibidem.

31. BARBOSA, Rui. A Constituiçăo e os atos inconstitucionais. ApudBONAVIDES, Paulo. Op. cit., p. 249. 
americano da judicial review, muito embora, diferentemente daquele país, onde o Judiciário logo alcançou proeminência política, aqui, sua expressāo era pífia. Como, acuradamente, observou o Ministro JOSÉ NÉRI DA SILVEIRA, "embora a Constituição do Império, no art. 151, estipulasse que o 'poder judicial é independente', certo é que, na quadra monárquica, ele se limitava a dirimir as controvérsias de direito privado, escapando, por inteiro, ao seu controle, os atos da administração pública". ${ }^{32}$ Se, assim, era no Império, não foi muito diferente na primeira República.

Será com a Constituição de 1934 que, pela primeira vez, se fará inserir no texto da Lei Maior a possibilidade do Judiciário ser provocado para pronunciar-se em abstrato sobre a inconstitucionalidade de uma lei. Como, porém, não foram curtos nem poucos os períodos de exceção da história política do País, já na Carta outorgada de 1937, o poder do Judiciário é apequenado, vez que decisão sua, declaranḋ a inconstitucionalidade de uma lei, noderia ser reexaminada pelo parlamento, se o presidente da República julgasse ser a lei "necessária ao bem-estar do povo, à promoção ou defesa de interesse nacional de alta monta". A Constituição de 1946 põe fim ao Estado Novo, e retoma, neste particular, os delineamentos da Constituiçāo de 1934. A Constituição de 1967 manteve a possibilidade da interposição de ação dire ta de declaração de inconstitucionalidade que, até então, era e continuou sendo de competência exclusiva do Procurador-Geral da República. Somente com a Constituição de 1988 é que foi ampliado o leque de legitimados ativos para aforarem esse tipo de ação. ${ }^{33}$

Assim, constata-se que, no Brasil, se caminhou em direção a um sistema misto muito próprio. Não há um tribunal constitucional nos moldes europeus, nem tão pouco o Supremo Tribunal Federal exerce, exclusivamente, a judicial review. O STF, tanto pela regra do sistema difuso, em sede de recurso extraordinário, irá julgar, em última instância, da constitucionalidade dos atos normativos aplicados ao caso concreto, como também, será de sua competência originária e única, pela regra do sistema concentrado, julgar das ações diretas de inconstitucionalidade.

O fato de ser híbrido o sistema em nada diminui a importância política do Judiciário que, ao menos teórica e formalmente, em processo gradativo, tem ganhado proeminência. Nesse sentido mereceria detida análise o sistema constitucional positivo vigente. Porém, tal exercício escapa aos limites e objetivos deste breve ensaio. Importa, agora, esboçar uma análise crítica da teoria e, também, do modelo que até aqui foi descrito.

32. Op. cit., p. 2.

33. O art. 103, da Carta de 1988, relaciona os legitimados para a propositura da ADIn: O Presidente da República; a Mesa do Senado Federal; a Mesa da Cámara dos Deputados; Mesa de Assembléia Legislativa; o Governador de Estado; o Procurador-Geral da República; Conselho Federal da Ordem dos Advogados do Brasil; partido político com representaçāo no Congresso Nacional; confederaçăo sincical ou entidade de classe de âmbito nacional. Sobre a evolução histórica para um sistema misto no Brasil, ver BONAVIDES, Paulo. Op. cit., pp. 257/262. 


\section{O Judiciário - democracia e poder}

Seguindo a lógica da teoria arquitetada no modelo liberal de Estado, como já mencionado, o Judiciário seria um poder quase sem poder. Primeiro, porque estritamente vinculado ao direito positivado. Segundo, por ser um poder inerte, que somente atua se motivado pelas partes, para dizer o direito, no exato limite da lide gerada em um caso concreto.

Pelas rápidas notícias históricas referidas, sabe-se que tal perfil veio sofrendo profundas alterações. Acertadamente, observou FERNANDO RUIVO que "os três poderes básicos crescentemente se interpenetram, irrompendo no espaço que, inicialmente, a cada um havia sido atribuído". ${ }^{34}$ No Brasil, por exemplo, é indisfarçável a avidez do Poder Executivo pela atividade legislativa. As inúmeras medidas provisórias, com suas infindáveis reedições, são uma amostra generosa do desvio da idealização original do modelo.

Na concepção de MONTESQUIEU, se o Executivo faz as próprias leis que executa, o despotismo está às portas. Contudo o que se observa, hoje, é que o Legislativo perdeu a hegemonia da produção das leis. Sob o pretexto da necessidade de dar respostas eficazes e rápidas aos problemas econômicos, gradativamente, e de forma sistemática, o Executivo tem usurpado a função do Legislativo.
Nessa conjuntura que aos poucos foise estabelecendo, cabe, perfeitamente, a pergunta pelo Poder Judiciário. Assim formulou-a, FERNANDO RUIVO:

"Será que, no momento em que o Legislativo vê apagar-se parte da sua função de controle do Executivo, o Judicial vai saltar em defesa da idéia de soberania popular (até aí consumada no Parlamento) incorporando-a e, desse modo, prefigurando as condições para se assumir como verdadeiro poder ao assegurar a proteção do cidadão contra as arbitrariedades do Estado e do Estado existente em cada cidadão?"35

Importa, portanto, que o protagonismo que vem assumindo o Judiciário seja avaliado a partir do critério da democracia e da garantia dos direitos fundamentais. À guisa de conclusão deste estudo, gostaríamos de apontar três respostas, ou melhor, indicar três tendências de respostas. A classificação é mero esforço de sistematização, sem preocupação de estabelecer paralelo com correntes de peirsamento jurídico.

\subsection{O Judiciário - poder impotente}

A despeito da importância que teria o Judiciário alcançado na configuração do estado contemporâneo, há inegável desconfiança quanto às suas reais possibilidades de responder, a contento, às demandas sociais hodiernas.

34. RUIVO, Fernando. Aparelho jucicial, estado e legitimaçăo. In FARIA, José Eduardo (Org.). Direito e justiça - a funçăo social do judiciário. 2. ed., São Paulo: Ática, 1994, p. 76.

35. Idem. p. 77. 
Apenas para mencionar um exemplo, vale a referência aos direitos coletivos ou difusos. Estes direitos diferentemente dos direitos individuais tradicionais não demandam apenas a proteção do Estado contra eventuais violaçōes, mas implicam no envolvimento da própria administração pública para promovê-los, ensina CARLOS FREDERICO MARÉS DE SOUZA FILHO. Para ele, "com o advento de novos direitos cuja medida não cabe $\epsilon$ m catálogo codificado e que exigem 'permanente ação do Estado, com vistas a financiar subsídios, remover barreiras sociais e econômicas', o Judiciário já não tem parâmetro subjetivo para o julgamento. Sem parâmetro, perde seu fundamento de legitimidade, se transforma em ente político, como não é representativo, pōe em risco a democracia". ${ }^{36} \mathrm{~A}$ questão tem sido formulada de diversas maneiras. RUIVO faz uso de metáfora esclarecedora ao dizer que o estado capitalista organizado, a despeito das modificações estruturais tremendas sofridas pelc sistema de um século para cá, "continua a respirar com os pulmões da teoria democrático-liberal do século XIX". ${ }^{37}$

\section{O direito do Estado liberal moderno} está assentado na concepção de direitos individuais, sujeito de direito, bens (objetos de direito). Esta concepção positivouse em várias constituições. A propósito mencionamos a portuguesa de 1822 , que dispunha: "A Constituição Política da nação portuguesa tem por objetivo manter a liberdade, segurança e propriedade de todos os portugueses". (grifamos)

Assim, como bem observa MARÉS DE SOUZA FILHO, "cada vez que se fala em direito, há que se buscar para a lógica do sistema um titular, uma pessoa, um sujeito de direitos, individual, ainda que seja uma ficção. De outro lado é necessário que se tenha um bem, uma coisa, um objeto que componha este patrimônio individual", ${ }^{38}$ Por esta razão, este autor refere-se a direitos invisíveis. Uma vez que os direitos coletivos e difusos não se enquadram no molde paradigmático do conflito entre direitos individuais - onde o direito de um entra em confronto com o direito de outro reclamando uma decisão definitiva - eles são invisíveis. Isto é, não tem o Judiciário instrumental formatado para deles dar conta. Por isso, teme-se que nestas circunstâncias o judiciário, "sem parâmetro, [perca] seu fundamento de legitimidade e se trans. forme em ente politico e, como nảo é representativo, [ponha] em risco a democracia". 39

As suspeitas quanto às reais possibilidades do Judiciário e sua eficácia estão, também, vinculadas à morosidade dos procedimentos e ao seu alto custo, que marginaliza parte significativa da população.

\footnotetext{
36. SOUZA FILHO, Carlos Frederico Marés. Os direitos invisiveis. In Os sentidos da democracia: políticas do dissenso e a hegemonia global. Petrópolis: Vozes; Brasilia: NEDIC, 1999, pp. 333-334.
}

37. Op. cit., p. 76 .

38. Op. cit., p. 311.

39. Idem. p. 334. 


\subsection{O Judiciário - região dominante da ideologia dominante}

A partir de outra perspectiva o Judiciário aparece como portador privilegiado da cultura jurídica positivista e dogmática, sendo que, cativo de excessivo formalismo, não tem dado mostras de uma postura independente, criativa e avançada em relação aos problemas de ordem social mais cruciais. ${ }^{40} \quad$ Segundo CELSO CAMPILONGO, o Judiciário corporifica, concomitantemente, um subsistema dependente e independente que funciona conforme as necessidades do sistema político vigente. ${ }^{41} \mathrm{Em}$ sentido quase idêntico, FERNANDO RUIVO percebe o Judiciário "como, simultaneamente, aparelho repressivo e ideológico do estado e sua função enquanto região dominante $\mathrm{da}$ ideologia dominante".42

Para uma melhor compreensão desta leitura do judiciário, vale a pena, aqui, esboçar a linha de reflexão de FERNANDO RUIVO. Fazendo uso das categorias marxianas, tais como modo de produção, produto, distribuição e aparelho ideológico de estado, ele entende que, deixando de lado o engenho de símbolos e ideais abstratos que compõe a redoma em que o direito é envolvido pelas universidades e pelos tribunais, a atividade decisória, que constituí a razão de ser do aparelho judicial, seria apenas um dos elementos do modo de produção jurídi$\mathrm{co}$, a distribuição final do produto. Ressalta o referido autor que a aplicação da lei é o produto da produção jurídica e que, portanto, está determinada na sua estrutura pela estrutura da produção. Contudo, o Ju. diciário vai aparecer, perante a sociedade, na realização de sua atividade, como que em desconexão com o sistema político. A independência do Judiciário enfaixa, para RUIVO, uma dupla ficção. De um lado, há um aparente distanciamento do sistema político - o Judiciário é um poder empurra. do para a sociedade, para fazer parecer que o Estado mesmo não se imiscui nas ques. tões privadas -- e por outro, um distanciamento da sociedade, até para poder operar com isenção, ancorando-se numa idealizada observância estrita da lei. Assim, por tão bem ocultar a vinculação com o político e com a sociedade, o Judiciário constituiria locus privilegiado da ideologia dominante. Segundo RUIVO "cada vez mais se teoriza a independência do juiz na medida em que este, cada vez mais, se transforma em funcionário público".43

Este tipo de análise, desde uma perspectiva sociológica ou política, é importante para o fornecimento de parâmetros

\footnotetext{
40. Neste sentido ver Antộnio Carlos Wolkmer, para quem o Judiciário constitui "um órgão elitista que, quase sempre oculladu pelo 'pseudoneutralismo' e pelo formalismo pomposo, age com demasiada submissáo aos citames da ordem dominante e move-se através de mecanismos burocráticos-procedimentalistas onerosos, inviabilizando, pelos seus custos, 0 acesso da imensa maioria da populaçáo de baixa renda". WOLKMER, Antônio Carlos. Pluralismo jurídico. Fundamentos de uma nova cultura no direito. São Paulo: Alfa Ômega, 1994, pp. 89-90.
}

41. CAMPILONGO, Celso F. Magistratura, sistema jurídico e sistema político. In FARIA, José Eduardo (Org.). Direito e justiça. A função social do judiciário. 2. ed., São Paulo: Ática, 1994, pp. 118-119.

42. Op. cit., p. 71.

43. Idem. pp. 73-76. 
críticos em relação ao campo jurídico, no qual, na maioria das vezes, prevalecem às idealizações abstratas de cunho meramente dogmático. No entanto, tem-se a impressão de que este exercício é sempre realizado por quem, de fora, observa um fenômeno inexorável, a fatalidade de um estado a serviço do sistema capitalista.

Será, porém, nas brechas que se abrem no sistema, pela constante busca de legitimação por parte do poder, que se encontra campo para os câmbios políticos. Assim, importa a quem atua enquanto operador do direito - quem está dentro - valer-se de tais enfoques, para assumir sua parcela de responsabilidade na luta pela transformação do Estado. Em suma, a consciência do Judiciário enquanto aparelho ideológico não deve ter caráter imobilizante, como se fadada estivesse a sociedade aos caprichosos e inexoráveis desígnios do mercado, que se instrumentalizou do Estado.

\subsection{O Judiciário e a idéia de Estado de direito}

A projeção de um estado, de quaiquer estado, parte de uma idealização a ser alcançada. Assim foi desde a República de Platão, passando pela Utopia de Thomas Morus, a Cidade do Sol de Campanella, o Contrato Social de Rousseau, a Sociedade
Comunista de Marx. É certo, porém, que na idealização do Estado moderno, tenha ele o matiz que tiver, a noção de estado de direito tornou-se emblemática.

A idéia de Estado de direito surgiu com o próprio nascimento do Estado moderno constitucional e desenvolveu-se com o direito administrativo. A limitação aos atos de império constitui-se o núcleo do direito administrativo. Mas, o estado de direito não importa tão-somente em limitação à administração, mas, igualmente, vincula e limita olegislador à Lei Fundamental. Corolário destas premissas é a exigência de um órgão, que exerça controle jurisdicional, ${ }^{44}$ para "impedir que o Estado de Direito democrático se perverta em uma ditadura parlamentar da maioria". ${ }^{45}$

De tal sorte que, em última instância, prevalece o princípio da soberania da Carta Constitucional, como fundamento do Estado de direito. E, para que seja garantida a soberania da Lei Fundamental, o Judiciário, através de sua Corte Suprema, tem sido galgado à condição de guardião da Constituição. Cábe a cle colmatar as lacunas que sempre existirão na lei, declarar a inconstitucionalidade de leis e atos normativos do legislativo e do executivo que afrontem a Constituição, desde que provocado para tanto, incidental ou diretamen-

44. Se bem que, em certos paises. dentre os quais a França é exemplo típico, o controle da constitucionaidade não é jurisdicional. mas antes, é propriamente político. Vale dizer, nestes paises não concebe a existência de um Tribunal Constitucional. O Conseil Constitutionnel é antes um örgāo politico totalmente desvinculado do Poder Judiciário. Há razōes históricas com justificativas teoréticas para o caso francés. Também, no antigo modelo soviético, não havia lugar para um Tribunal Constitucional, mas por motivo outro. Rejeitando a doutrina burguesa da separaçăo dos poderes, se entendia que o poder estava reunido no único órgáo supremo, de direta emanaçáo popular, cujos componente foram eleitos pelo povo. Razáo porque, inadmissivel o controle da constitucionalicade exercido por orgåo estranho ao parlamento, expressáo da soberania popular. Sobre o tema: CAPPELETTI, Mauro. Controle judicial de constitucionalidade das leis no direito comparado. Porto Alegre: Fabris, 1984, pp. 31/44 e 94 ss.

45. KIMMINICH, Otto. A jurisdição constitucional e o princípio da divisẫo de poderes. Revista de Informação Legislativa, Ano 1, n 1 , mar/1964 - Brasilia, Senado Federal, p. 286. 
te. Em suma, ao Judiciário caberá a interpretação da Constituição para, em última instância, dizer o que diz a Constituição.

\section{Não temos uma tradição} constitucionalista bem demarcada. Os governantes de plantão têm, desde a primeira República, suspendido garantias e outorgado novas Cartas. E, atualmente, a força da Constituição de 1988 tem sido debilitada por constantes emendas, que desnaturam sua feição primeira. Porém, é certo que ao Supremo Tribunal Federal a Carta Magna conferiu poder relevantíssimo, especialmente, quando ampliou o rol dos legitimados para a propositura da ação direta de inconstitucionalidade. ${ }^{46}$

A história testemunhará se os direitos individuais e coletivos assegurados pela Constituição terão prevalência sobre as chamadas razões do Estado e/ou da empresa, ou, dito de outra forma, se o STF estará a serviço da defesa da democracia e do exercício pleno da cidadania, impondo-se como voz asseguradora da soberania popular expressa na Iei Fundamenta! do País. Por enquanto, essa expressão ainda é tímida. De qualquer sorte, neste campo, um passo em falso, para usar a expressão de MARÉS DE SOUZA FILHO, poderá levar à tirania, ${ }^{47}$ fazendo periclitar a democracia.

A outorga de competência ao STF para julgar da constitucionalidade das leis ordinárias é decorrência necessária do princípio do Estado de direito, que exige controle jurisdicional independente.

Tal competência deverá ser assumida na defesa intransigente das normas e diretrizes constitucionais, porque é lugar comum o fato de o princípio da divisão dos poderes - que serviu para combater o absolutismo - ter "caráter meramente formal, permitindo a sua utilização como simples roupagem de ditaduras". ${ }^{48}$ Eis aí o desafio para o Judiciário, idealizado como instância máxima garantidora da cidadania e da democracia, no estado de bem-estar social projetado pela Constituição de 1988.

\section{Bibliografia}

BOBBIO, Norberto. A teoria das formas de formas de governo. 3. ed., Brasília: Editora Universitária de Brasília, 1980.

BONAVIDES, Paulo. Teoria do estado. 2. ed., Rio de Janeiro: Forense, 1980.

Curso de Direito Constitucional. 4. ed., São Paulo: Malheiros, 1993, p. 67.

CAMPILONGO, Celso F. Magistratura, sistema jurídico e sistema político. In FARIA, José Eduardo (Org.). Direito e justiça. A função social do judiciário. 2. ed., São Paulo: Atica, 1994.

CANOTILHO, José Joaquim Gomes. Direito Constitucional. 6. ed., Coimbra: Almedina, 1993, p. 64.

CAPPELlETTI, Mauro. Controle judicial de constitucionalidade das leis no direito comparado. Porto Alegre: Fabris, 1984.

KIMMINICH, Otto. A jurisdição constitucional e o princípio da divisão de poderes. Revista de Informação Legislativa, Ano 1, nº 1, mar/1964 Brasília, Senado Federal.

46. Registra Gilmar Ferreira Mendes que a Constituição de 1988 alterou, de maneira radical, a situação, conferindo ênfase não mais ao sistema difuso ou incidente, mas ao modelo concentrado, uma vez que as questóes consfitucionais passam a ser veiculadas, fundamentalmente, mediante ação direta de inconstitucionalidade perante o Supremo Tribunal Federal. MENDES, Gilmar Ferreira. Jurisdição constitucional: o controle abstrato no Brasil e na Alemanha. São Paulo: Saraiva, 1996, p. 80.

47. Op. cit., p. 332.

48. KIMMINICH, Otto. Op. cit., p. 290. 
MENDES, Gilmar Ferreira. Jurisdiçāo constitucional: o controle abstrato no Brasil e na Alemanha. São Paulo: Saraiva, 1996.

MONTESQUIEU. Do espírito das leis. São Paulo: Brasil Editora, 1960.

RUIVO, Fernando. Aparelho judicial, estado e legitimação. In FARIA, José Eduardo(Org.). Direito e justiça - a função social do judiciário. 2. ed., São Paulo: Ática, 1994.

SILVA, José Afonso da. Curso de direito constitucional. 8. ed., São Paulo: Malheiros, 1992, p. 484.
SILVEIRA, José Néri da. Aspectos institucionais e estruturais do poder jurídico brasileiro. In TEIXEIRA, Sálvio de Figueiredo. O judiciario e a constituiçāo. São Paulo: Saraiva, 1994.

SOUZA FILHO, Carlos Frederico Marés. Os direitos invisíveis. In Os sentidos da democracia: politicas do dissenso e a hegemonia global. Petrópolis: Vozes: Brasília: NEDIC, 1999.

WOLKMER, Antônio Carlos. Pluralismo jurídico. Fundamentos de uma nova cultura no direito. Sâo Paulo: Alfa Ômega, 1994. 